\title{
Genome-wide analysis and expression profiling of calcium- dependent protein kinases in potato (Solanum tuberosum)
}

\author{
Robert Gromadka $^{1} \cdot$ Jarosław Cieśla $^{1} \cdot$ Krzysztof Olszak $^{1} \cdot$ Jadwiga Szczegielniak $^{1} \cdot$ \\ Grażyna Muszyńska ${ }^{1} \cdot$ Lidia Polkowska-Kowalczyk $^{1}$
}

Received: 16 February 2017 / Accepted: 27 October 2017 / Published online: 9 November 2017

(c) The Author(s) 2017. This article is an open access publication

\begin{abstract}
Calcium-dependent protein kinases (CDPKs or $\mathrm{CPKs}$ ), unique to plants and some protists, are involved in growth and developmental processes as well as in defence against diverse environmental stresses. CDPKs are encoded by multi-gene families. Despite extensive studies of the CDPKs in many species, information about the evolutionary history and expression patterns of the CDPK family in the staple crop potato (Solanum tuberosum) remains poorly known. In this study, we performed bioinformatics analysis of the potato whole genome sequence and identified 23 potential $C D P K$ genes. These genes are located in 11, of 12 , potato chromosomes. Based on the phylogenetic tree and gene structures, the CDPKs were divided into four subfamilies. To determine their expression, reverse transcription quantitative polymerase chain reaction (RT-qPCR) analysis was carried out for the $C D P K$ genes in different organs of potato such as young and mature leaves, stems, young shoots, roots, stolons, swollen stolons, flowers and tubers. The CDPKs were expressed in all the organs analysed, but their expression patterns varied greatly. The expression of some $C D P K s$ was strongly organ specific, for example StCPK13 and StCPK18 was found only/mostly in flowers. In Solanum genotypes differing in resistance to Phytophthora infestans, the expression and activity of CDPKs increased in response to a $P$. infestans elicitor with different kinetics and intensity. The expression levels and activity of the CDPKs
\end{abstract}

Electronic supplementary material The online version of this article (https://doi.org/10.1007/s10725-017-0341-9) contains supplementary material, which is available to authorized users.

Lidia Polkowska-Kowalczyk

lidekp@ibb.waw.pl

1 Institute of Biochemistry and Biophysics, Polish Academy of Sciences, Pawińskiego 5a, 02-106 Warsaw, Poland correlated positively with the level of the resistance. Our results support earlier suggestion that CDPKs are involved in potato organ development and defence against stresses. We provide new information about the $C D P K$ gene family in the potato and a perspective on its evolutionary history and biological roles of the individual kinases.

Keywords Calcium-dependent protein kinases (CDPKs) . Expression pattern · Gene family $\cdot$ Phytophthora infestans . Solanum tuberosum

\section{Introduction}

Calcium plays an important role as a universal second messenger in the control of developmental processes and in signal transduction. Changes in calcium ion concentration are sensed, among others, by calcium-dependent protein kinases (CDPKs, also named CPKs). CDPKs are Ser/Thr protein kinases typically comprising five domains: an $\mathrm{N}$-terminal variable domain, a catalytic domain (CD), an autoinhibitory junction domain (JD), a calmodulin-like domain (CLD), and a C-terminal domain (Hrabak et al. 2003). The N- and $\mathrm{C}$-terminal domains are variable, differing in length and amino-acid composition. Moreover, the $\mathrm{N}$-terminal domain often bears myristoylation sites associated with the subcellular localization of the kinase. The specific functions of CDPKs are determined by these variable domains (Hrabak et al. 2003). In a typical CDPK the calmodulin-like domain harbours four EF-hand motifs for $\mathrm{Ca}^{2+}$ binding, and the binding of $\mathrm{Ca}^{2+}$ activates the kinase (Cheng et al. 2002). CDPKs are important sensors and effectors of the $\mathrm{Ca}^{2+}$ flux in plants. CDPKs have different subcellular locations including cytosol, nucleus, plasma membrane, endoplasmic reticulum, peroxisomes, mitochondrial outer membrane, and oil 
bodies, indicating their possible diverse functions ( $\mathrm{Lu}$ and Hrabak 2002).

The CDPKs are multifunctional, which is reflected by the increasing number of their substrates being discovered. Numerous studies have demonstrated that CDPKs play key roles in the regulation of plant growth, development, and abiotic and biotic stress resistance (for review see Klimecka and Muszyńska 2007). Some $C D P K$ genes have been shown to be involved in pollen tube growth (Estruch et al. 1994), root development (Ivashuta et al. 2005) and cell division and differentiation (Yoon et al. 1999).

Individual CDPKs in various species have been assigned defined roles. Thus, tomato LeCDPK2 regulates ethylene biosynthesis in response to wound signalling (Kamiyoshihara et al. 2010); Arabidopsis AtCPK1/2/4/5/11 phosphorylate and thereby activate NADPH oxidase to promote reactive oxygen species (ROS) production in response to abiotic and biotic stimuli (Gao et al. 2013); rice OsCPK4 participates in rice tolerance to salt and drought stress by protecting cellular membranes from lipid peroxidation (Campo et al. 2014), grapevine gene VaCPK29 confers tolerance to heat and osmotic stresses (Dubrovina et al. 2017), whereas $\mathrm{ZmCPK} 11$ is involved in touch- and wound-induced pathways in maize (Szczegielniak et al. 2012). CDPKs are widely involved in various types of disease resistance (Boudsocq et al. 2010; Boudsocq and Sheen 2013; Romeis and Herde 2014; Wang et al. 2015). They regulate the plants' defence response locally and also systemically (Romeis and Herde 2014). AtCDPK $1 / 2$ modulate the initiation of programmed cell death, while AtCDPK4/5/6/11 phosphorylate specific WRKY transcription factors to regulate immune gene expression. AtCPK1 plays a positive role in resistance to various pathogens by promoting the salicylic acid (SA) signalling pathway (Coca and San Segundo 2010). NtCDPK2 is involved in the induction of $C f-4 / A v r 4-$ and $C f$-9/Avr9-dependent hypersensitive response (HR) (Romeis et al. 2001).

The CDPKs have been identified in plants (Harmon et al. 2001; Asano et al. 2005), protists (Billker et al. 2009), oomycetes (Broad Institute of Harvard and MIT 2010), and green algae (McCurdy and Harmon 1992; Baillie et al. 2000), but not in any animal or true fungal genome (Zhang and Choi 2001; Hrabak et al. 2003). Plant genomes carry large numbers of $C D P K$ genes; 34 in Arabidopsis thaliana (Cheng et al. 2002; Hrabak et al. 2003), 41 in diploid cotton (Gossypium raimondii) (Liu et al. 2014), 29 or 31 in rice (Oryza sativa) (Asano et al. 2005; Ray et al. 2007, respectively), 20 in wheat (Triticum aestivum) (Li et al. 2008), 35 or 40 in maize (Zea mays) (Ma et al. 2013; Kong et al. 2013, respectively), 29 in tomato (Solanum lycopersicum) (Wang et al. 2015; Hu et al. 2016), and 30 CDPK genes in poplar (Populus trichocarpa) (Zuo et al. 2013). Slightly less numerous are $C D P K$ gene families in cucumber (Cucumis sativus) and grape (Vitis vinifera) with 19 members in both plants (Xu et al. 2015; Zhang et al. 2015).

Despite extensive studies of $C D P K \mathrm{~s}$ in many species, still little is known about this gene family in the important crop potato (Solanum tuberosum). Only five isoforms have been characterized so far. It is known that CDPKs are involved in tuber development (Raíces et al. 2001, 2003). StCDPK1 transcript was observed in mesh bulbs and that of $S t C D P K 2$ mainly in the leaves. StCDPK1 also plays a role in gibberellic acid (GA) signaling and influences tuberization (Gargantini et al. 2009) while StCDPK2 is associated with plant growth and development (Giammaria et al. 2011). An application of abscisic acid (ABA) or GA had no significant effect on the activity and expression of StCDPK2 (Giammaria et al. 2011), while treatment with jasmonic acid decreased StCDPK2 expression at both these levels (Ulloa et al. 2002). The expression profile of StCDPK3 under different conditions has indicated that $\mathrm{ABA}$ functions as a positive and $\mathrm{GA}$ as a negative regulator of its expression. Agrobacterium tumefaciens-mediated transformation allowed demonstrating that $S t C D P K 3$ was expressed in early induced stolons and its expression decreased in advanced tuber formation stages (Grandellis et al. 2012). As in other species, StCDPK4 and StCDPK5 have been shown to phosphorylate and thereby activate NADPH oxidase to promote reactive oxygen species (ROS) production in response to biotic stimuli (Kobayashi et al. 2007).

The availability of the whole genome sequence of the potato (Potato Genome Sequencing Consortium 2011) allowed us to carry out a comprehensive in silico search for $C D P K$ genes and their subsequent expression profiling. RT-qPCR expression analysis was carried out for the $C D P K$ genes in different organs of potato. The activity and expression of the CDPKs were also determined in Solanum genotypes expressing different resistance against the pathogenic oomycete Phytophthora infestans causing late blight, the most destructive potato disease.

\section{Materials and methods}

\section{Identification of calcium-dependent protein kinase genes in potato}

\section{Gene retrieval}

All S. tuberosum genes identified in the genomic annotation as encoding a calcium-dependent protein kinase were downloaded from the public databases Spud DB (http:// potato.plantbiology.msu.edu/) and Sol Genomics Network (http://solgenomics.net/). As references for the identification of $C D P K$ genes we used GenBank NCBI sequences of potato genes described in the literature [StCDPK] 
accession number (acc. no.) DQ507862, StCDPK2 acc. no. AF418563, StCDPK3 acc. no. JF308510, StCDPK4 acc. no. AB279737, StCDPK5 acc. no. AB279738]. Comparison of particular genes was performed using BLAST program (The Basic Local Alignment Search Tool). For analysis, we used 21 genes annotated as calcium-dependent protein kinases in the above-mentioned databases and two genes, StCDPK3 and StCDPK5, absent from those bases. Finally, 23 potato genes were identified as CDPKs (Table 1 and Supplementary material 1) and were subjected to further analyses. Thirty-four Arabidopsis thaliana CDPK genes used for phylogenetic analysis were downloaded from GenBank NCBI (Supplementary material 2).

\section{Phylogenetic analysis and gene structure prediction}

Full-length amino acid sequences of 23 potato and $34 \mathrm{~A}$. thaliana CDPKs were aligned using ClustalX version 2.0 program with default parameters (Larkin et al. 2007). A phylogenetic tree was constructed according to the neighborjoining method using MEGA 7.00 program (Tamura et al. 2004; Kumar et al. 2016).

The gene structures of the CDPKs were predicted by The Gene Structure Display Server (GSDS) version 2.0 (Hu et al. 2015).

Protein domains were predicted by PROSITE scan (Sigrist et al. 2013), and myristoylation sites by NMT-The MYR Predictor script (http://mendel.imp.ac.at/myristate/ SUPLpredictor.htm).

Table 1 Characteristics of Solanum tuberosum CDPK genes

\begin{tabular}{|c|c|c|c|c|c|c|c|}
\hline Name & PGSC Transcript ID & Genbank no. (NCBI) & Length (AA) & $\begin{array}{l}\text { Molecular } \\
\text { weight (kDa) }\end{array}$ & $\begin{array}{l}\text { Myris- } \\
\text { toylation } \\
\text { site }\end{array}$ & No. of introns & Chromo-some \\
\hline $\begin{array}{l}\text { StCPK1 } \\
\text { (former } \\
\text { StCDPK1) }\end{array}$ & PGSC0003DMT400071663 & XM_006365894 & 509 & 56.6 & + & 6 & 12 \\
\hline $\begin{array}{l}\text { StCPK2 } \\
\text { (former } \\
\text { StCDPK2) }\end{array}$ & PGSC0003DMT400057484 & XM_006346152 & 521 & 57.9 & + & 7 & 7 \\
\hline $\begin{array}{l}\text { StCPK3 } \\
\text { (former } \\
\text { StCDPK3) }\end{array}$ & Not found & $\begin{array}{l}\text { JF308510 } \\
\text { NM_001288527 }\end{array}$ & 554 & 63.0 & + & 7 & $?$ \\
\hline $\begin{array}{l}\text { StCPK4 } \\
\text { (former } \\
\text { StCDPK4) }\end{array}$ & PGSC0003DMT400043320 & XM_006365245 & 567 & 63.4 & - & 6 & 10 \\
\hline $\begin{array}{l}\text { StCPK5 } \\
\text { (former } \\
\text { StCDPK5) }\end{array}$ & Not found & $\begin{array}{l}\text { AB279738 } \\
\text { NM_001287861 }\end{array}$ & 535 & 60.0 & - & $?$ & $?$ \\
\hline StCPK6 & PGSC0003DMT400060262 & XM_006345687 & 503 & 56.4 & - & 6 & 5 \\
\hline StCPK7 & PGSC0003DMT400002592 & XM_006350871 & 578 & 64.8 & + & 6 & 5 \\
\hline StCPK8 & PGSC0003DMT400027809 & XM_006366477 & 533 & 60.0 & + & 7 & 1 \\
\hline StCPK9 & PGSC0003DMT400054983 & XM_006348373 & 598 & 67.6 & - & 6 & 1 \\
\hline StCPK10 & PGSC0003DMT400021055 & XM_006351162 & 524 & 59.4 & + & 7 & 10 \\
\hline StCPK11 & PGSC0003DMT400067082 & XM_006353564 & 501 & 56.4 & - & 6 & 6 \\
\hline StCPK12 & PGSC0003DMT400072554 & XM_006339117 & 607 & 68.3 & - & 6 & 10 \\
\hline StCPK13 & PGSC0003DMT400018575 & XM_006364680 & 544 & 60.4 & + & 6 & 10 \\
\hline StCPK14 & PGSC0003DMT400025581 & XM_006342017 & 540 & 61.0 & + & 7 & 4 \\
\hline StCPK15 & PGSC0003DMT400002331 & XM_006351851 & 505 & 57.0 & - & 6 & 11 \\
\hline StCPK16 & PGSC0003DMT400058126 & XM_006343307 & 568 & 64.2 & + & 11 & 3 \\
\hline StCPK17 & PGSC0003DMT400024436 & XM_006356324 & 524 & 59.0 & + & 7 & 11 \\
\hline StCPK18 & PGSC0003DMT400011824 & XM_006349734 & 535 & 60.0 & + & 8 & 12 \\
\hline StCPK19 & PGSC0003DMT400014939 & XM_006352199 & 517 & 57.8 & + & 7 & 8 \\
\hline StCPK20 & PGSC0003DMT400054991 & XM_006348361 & 582 & 64.6 & + & 7 & 1 \\
\hline StCPK21 & PGSC0003DMT400072292 & XM_006339122 & 638 & 70.2 & - & 7 & 10 \\
\hline StCPK22 & PGSC0003DMT400009177 & XM_006340676 & 564 & 63.6 & + & 11 & 2 \\
\hline StCPK23 & PGSC0003DMT400069175 & XM_006347224 & 536 & 61.1 & + & 8 & 6 \\
\hline
\end{tabular}




\section{Plant material and growth conditions-in vitro cultures}

Plants of Solanum tuberosum cultivar (cv) Bzura and Solanum scabrum (received from IHAR-PIB, Młochów Research Center, Poland, Plich et al. 2015) and Solanum tuberosum clone H-8105 were cultured in vitro as described previously (Polkowska-Kowalczyk et al. 2004). The plants were grown under controlled conditions: day/ night $16 \mathrm{~h} / 8 \mathrm{~h}$, fluorescent lamp $150 \mu \mathrm{mol} \mathrm{m}{ }^{-2} \mathrm{~s}^{-1}$ for $16 \mathrm{~h}$, day/night temperature of $22 / 18{ }^{\circ} \mathrm{C}$ and propagated at $4-6$ week intervals.

\section{Plant material and growth conditions-plants grown in soil}

After 4 weeks of growth in vitro, Bzura plants were transferred to soil and were grown in a green-house under conditions described above. At 6-8 weeks after planting, young and mature leaves, young shoots, stolons, swollen stolons, stems, flowers, roots and tubers were harvested for analysis. The collected samples were immediately frozen in liquid nitrogen and stored at $-80{ }^{\circ} \mathrm{C}$.

\section{Pathogen elicitor}

The pathogen Phytophthora infestans (isolate MP618 from 2005, of the following race: 1.2.3.4.(5).6.7.10.11, A1 mating type and resistant to metalaxyl) received from IHARPIB, Młochów Research Center, Poland, was maintained on rye agar medium at $15^{\circ} \mathrm{C}$ in the dark. Culture filtrate $(\mathrm{CF})$, which served as an elicitor, was prepared from the pathogen grown in liquid medium. After 6 weeks of growth, the medium was separated from the oomycete, dialysed against water for $48 \mathrm{~h}$ and lyophilised. The $\mathrm{CF}$ residue was dissolved in distilled water and quantified as $\mu \mathrm{g}$ glucose equivalents $\mathrm{ml}^{-1}$, as described earlier by Polkowska-Kowalczyk et al. (2004).

\section{Elicitor treatment of leaves}

Leaves of $S$. tuberosum cv Bzura, S. tuberosum clone H-8105, and Solanum scabrum, which exhibited field resistance, susceptibility and non-host resistance to $P$. infestans, respectively, were harvested from 4-week-old plants grown in vitro. The leaves were placed on moist filter paper in Petri dishes and the culture filtrate was applied in small droplets on the abaxial surface of each leaf at a dose of $0.67 \mu \mathrm{g}$ glucose equivalents. $\mathrm{g}^{-1}$ fresh weight $(\mathrm{FW})$. As a control an equal volume of distilled water was applied. Leaves were incubated at $25{ }^{\circ} \mathrm{C}$ under continuous white light of 150 $\mu \mathrm{mol} \mathrm{m} \mathrm{m}^{-2} \mathrm{~s}^{-1}$ from fluorescent tubes (Pila, Poland) and taken for analysis after 1, 3, 6, 18, 24, and $30 \mathrm{~h}$ (PolkowskaKowalczyk et al. 2004).

\section{RNA isolation}

We used two methods for RNA isolation. Total RNA was isolated from samples ( $0.1 \mathrm{~g} \mathrm{FW})$ of young and mature leaves using the TRIzol reagent according to manufacturer's protocol (Molecular Research Center, INC.). For RNA isolation from other organs, to avoid the gelling of starch and low recovery of RNA, a modified method of Kumar et al. (2007) was used. Briefly, $0.1 \mathrm{~g} \mathrm{FW}$ of frozen tissue was ground with liquid nitrogen in a mortar to a fine powder. RNA was extracted with $500 \mu \mathrm{L}$ of extraction buffer containing $100 \mathrm{mM}$ Tris-HCl (pH 8), 5 mM EDTA (pH 8), $100 \mathrm{mM} \mathrm{NaCl}, 0.5 \%$ SDS and $1 \% \beta$-mercaptoethanol. The extract was vortexed for $5 \mathrm{~min}$ at room temperature (RT). Next, it was centrifuged (5 min, $11,000 \times g)$ and supernatant was transferred to new tubes, $250 \mu \mathrm{L}$ of chloroform was added and mixed for $15 \mathrm{~min}$. at RT, next $250 \mu \mathrm{L}$ of Trissaturated phenol ( $\mathrm{pH}$ 7.9) was added and mixed again for $15 \mathrm{~min}$. The mixture was centrifuged at $4{ }^{\circ} \mathrm{C}$ for $10 \mathrm{~min}$ at $14,000 \times g$ and upper phase $(550 \mu \mathrm{L})$ was transferred to a fresh tubes and extracted with an equal volume of Tris-saturated phenol ( $\mathrm{pH}$ 7.9): chloroform: isoamyl alcohol (25:24:1; $\mathrm{v}: \mathrm{v}: \mathrm{v})$ for $10 \mathrm{~min}$. After centrifugation as above, $500 \mu \mathrm{L}$ of upper phase was transferred to new tubes and RNA was precipitated with $50 \mu \mathrm{L}$ of $3 \mathrm{M}$ sodium acetate and $400 \mu \mathrm{L}$ isopropanol at $-80{ }^{\circ} \mathrm{C}$ for at least $1 \mathrm{~h}$. RNA was pelleted by centrifugation at $14,000 \times g$ for $30 \mathrm{~min}$ at $4{ }^{\circ} \mathrm{C}$. The RNA pellet was washed free of salts with 85,80 and $75 \% \mathrm{EtOH}$. The residual EtOH was evaporated on ice for about $10 \mathrm{~min}$ and RNA was dissolved in water.

Concentration and quality of RNA were estimated using NanoDrop 2000 spectrophotometer (ThermoScientific) at 260, 280 and $230 \mathrm{~nm}$. The extent of protein and carbohydrate/phenolic contamination was assessed by $\mathrm{A}_{260} \mathrm{I}_{280}$ and $\mathrm{A}_{260} / 230$ ratios, respectively.

\section{Reverse transcription quantitative PCR}

First strand cDNA was synthesized using Enhanced Avian HS RT-PCR Kit (SIGMA-ALDRICH). After the cDNA synthesis reaction, $\mathrm{qPCR}$ was performed.

Primers were designed using the Primer Quest program http://eu.idtdna.com/PrimerQuest/Home/Index) (Supplementary material 3). The reaction mixture contained RealTime $2 \times$ HS-PCR Master Mix SYBR A (A\&A Biotechnology), specific forward and reverse primers (100 nM each), cDNA template (in three concentrations, each in duplicate), and water to $10 \mu \mathrm{L}$ of final volume. 
Reactions were performed in a Light Cycler LC480 (Roche) with an initial denaturation step of $95{ }^{\circ} \mathrm{C}$ for $1 \mathrm{~min}$. (A\&A kit) followed by 45 cycles of denaturation $\left(95^{\circ} \mathrm{C}\right.$ for $15 \mathrm{~s})$ and primer annealing-extension $\left(60{ }^{\circ} \mathrm{C}\right.$ for $1 \mathrm{~min}$.). Fluorescence was read during the annealing-extension step of each cycle. After cycling, melting point temperature analysis was performed in the range of $60-95^{\circ} \mathrm{C}$. In each experiment background range was adjusted automatically and the cycle threshold $(\mathrm{Ct})$ evaluation was adjusted manually. Quality of results was evaluated based on expected $\mathrm{Ct}$ differences among three cDNA amounts as well as product melting curves. Using three concentrations of cDNA permitted determining amplification efficiencies for each primer pair and normalization of all results to one cDNA concentration common for all genes. Expression of each target gene was calculated by the $\Delta \mathrm{Ct}$ method against the geometric mean of the $\mathrm{Ct}$ values for two reference genes (Vandesompele et al. 2002). The reference genes, elongation factor 1- $\alpha$ (efl $\alpha)$ (acc. no. AB061263.1) and cytoplasmic ribosomal protein L2 gene (acc. no. 39816659), were used as an endogenous control to normalize variance in the quality of RNA and the amount of cDNA used. The ratio between the target and reference gene expressions was presented as the final value.

\section{In-gel kinase assay}

The in-gel kinase assay was performed according to the method described by Szczegielniak et al. (2005), with slight modifications. Briefly, $0.3 \mathrm{~g}$ FW of frozen Solanum leaves was ground with glass beads in liquid nitrogen in a mortar. Proteins were extracted with $100 \mu \mathrm{L}$ of extraction buffer (50 mM Tris-HCl pH 7.5, $500 \mathrm{mM}$ sucrose, 4 mM EDTA, $4 \mathrm{mM}$ EGTA, $20 \mathrm{mM} \mathrm{NaF}, 100 \mathrm{mM} \beta$-glicerophosphate, $2 \mathrm{mM}$ PMSF, $10 \mathrm{mM}$ DTT, $40 \mu \mathrm{g} / \mathrm{mL}$ leupeptin, $10 \mu \mathrm{g} /$ $\mathrm{mL}$ aprotinin, $4 \mu \mathrm{g} / \mathrm{mL}$ pepstatin, $\left.200 \mu \mathrm{M} \mathrm{Na} \mathrm{VO}_{4}\right)$. The suspension was sonicated three times for $10 \mathrm{~s}$ each, centrifuged at $10,280 \times g$ for $10 \mathrm{~min}$ at $4{ }^{\circ} \mathrm{C}$. The supernatant was centrifuged again for $30 \mathrm{~min}$ at $4{ }^{\circ} \mathrm{C}$. Protein concentration was determined using bovine serum albumin (BSA) as the standard (Bradford 1976).

Proteins (from 15 to $30 \mu \mathrm{g}$ ) from the clarified homogenate were separated on $10 \%$ sodium dodecyl sulfate (SDS)polyacrylamide gels containing myelin basic protein (MBP; $0.25 \mathrm{mg} / \mathrm{mL}$ ) as the immobilized substrate of protein kinases.

After electrophoresis, SDS was removed by washing the gel three times for 30 min each with $25 \mathrm{mM}$ Tris, $\mathrm{pH}$ 7.5 , containing $0.5 \mathrm{mM}$ DTT, $0.1 \mathrm{mM} \mathrm{Na}_{3} \mathrm{VO}_{4}, 5 \mathrm{mM} \mathrm{NaF}$, $0.5 \mathrm{mg} \mathrm{mL}^{-1} \mathrm{BSA}$ and $0.1 \%(\mathrm{v} / \mathrm{v})$ Triton X-100 at room temperature. Next, the gel was equilibrated in $25 \mathrm{mM}$ Tris, $\mathrm{pH}$ 7.5 containing $5 \mathrm{mM} \mathrm{NaF}, 1 \mathrm{mM}$ DTT and $0.1 \mathrm{mM} \mathrm{Na}_{3} \mathrm{VO}_{4}$, for $18 \mathrm{~h}$ with three changes of the buffer. Then, the gels were pre-incubated for $30 \mathrm{~min}$ at $4{ }^{\circ} \mathrm{C}$ in $10 \mathrm{~mL}$ of reaction buffer (20 mM Tris, pH 7.5, $15 \mathrm{mM} \mathrm{MgCl}_{2}, 2 \mathrm{mM}$ DTT, and $0.33 \mathrm{mM} \mathrm{Ca}\left(\mathrm{CH}_{3} \mathrm{COOH}\right)_{2}$ or $2 \mathrm{mM}$ EGTA). Kinase activity was assayed for $1.5 \mathrm{~h}$ at $30{ }^{\circ} \mathrm{C}$ in the reaction buffer supplemented with $0.25 \mathrm{mM}$ ATP containing $50 \mu \mathrm{Ci}[\gamma 32 \mathrm{P}]$ ATP.

Unincorporated $[\gamma 32 \mathrm{P}]$ ATP was removed by washing the gels in 5\% (w/v) trichloroacetic acid containing 1\% (w/v) sodium phosphate. After washing, the gels were stained with Coomassie Brilliant Blue R250 (Sigma-Aldrich) and dried. The kinase activity was visualized by autoradiography or quantified using a PhosphorImager.

\section{Results}

\section{Identification and distribution of calcium-dependent protein kinase genes in the potato genome}

A genome-wide analysis of the $C D P K$ gene family in potato (Solanum tuberosum) was performed on the complete potato genome sequence (Potato Genome Sequencing Consortium 2011) using bioinformatics methods. Only five $C D P K$ genes had been reported earlier for $S$. tuberosum: StCDPK1, StCDPK2, StCDPK3, StCDPK4 and StCDPK5. Two nucleotide sequence databases were selected for an in silico search for additional genes (see Materials and methods). The first contains sequences from an international sequencing project for $S$. tuberosum group Phureja DM1-3 516 R44 (DM; AEWC00000000) and heterozygous diploid breeding line, S. tuberosum group Tuberosum RH89-039-16 (RH; ERP000627). The second base comprises sequences of plant genomes from the Asteraceae clade which includes the family Solanaceae. This database also contains a wealth of tools for comparative analysis of genomes.

Twenty-nine $C D P K$ genes automatically annotated as calcium-dependent protein kinases were found in the two databases, of which only 21 genes had all the domains typical for CDPKs. Because the previously identified $S t C D P K 3$ and $S t C D P K 5$ are absent from these bases, we used for further analyses $S t C D P K 3$ (cDNA and genomic) and $S t C D P K 5$ (cDNA) sequences deposited in GenBank (NCBI). Altogether, 23 potato $C D P K s$ were identified, designated StCPK1 - StCPK23 according to the proposed nomenclature for CDPK genes (Hrabak et al. 1996; Boudsocq and Sheen 2013) (Table 1 and Supplementary material 1). The CDPK genes are indicated by the three-letter abbreviation CPK followed by a number. The potato CDPKs identified in this study have structures typical for the CDPK family, comprising the $\mathrm{N}$-terminal and $\mathrm{C}$-terminal variable domains, the protein kinase domain, the autoinhibitory junction domain, and the calmodulin-like domain containing four calcium binding motifs called EF-hands (Supplementary material 4). Moreover, 14 of the potato CDPKs were found to contain predicted myristoylation sites at their $\mathrm{N}$-terminus. 
Among the 29 automatically annotated potato CDPKs there are eight atypical ones containing one or no calciumbinding motif. Information about these atypical kinases is included in the supplementary material (Supplementary material 5).

\section{Phylogenetic characterization and exon-intron structure analysis}

To establish the phylogenetic relationships among the $S t C D P K$ genes, a combined (S. tuberosum and A. thaliana) phylogenetic tree was constructed for the StCDPK amino acid sequences. The unrooted tree was generated from an alignment of 57 CDPK protein sequences, 23 potato and 34 A. thaliana ones. All these CDPKs could be broadly classified into four major subfamilies (subfamilies I, II, III and IV shown in Fig. 1). Subfamily I contained 11 StCDPKs: StCPK4, StCPK5, StCPK6, StCPK7, StCPK9, StCPK11, StCPK12, StCPK13, StCPK15, StCPK20, StCPK21, subfamily II 7 members: StCPK1, StCPK2, StCPK3, StCPK14, StCPK17, StCPK18, StCPK19, subfamily III 3 members: StCPK8, StCPK10, StCPK23, and subfamily IV only 2 StCDPKs: StCPK16 and StCPK22.

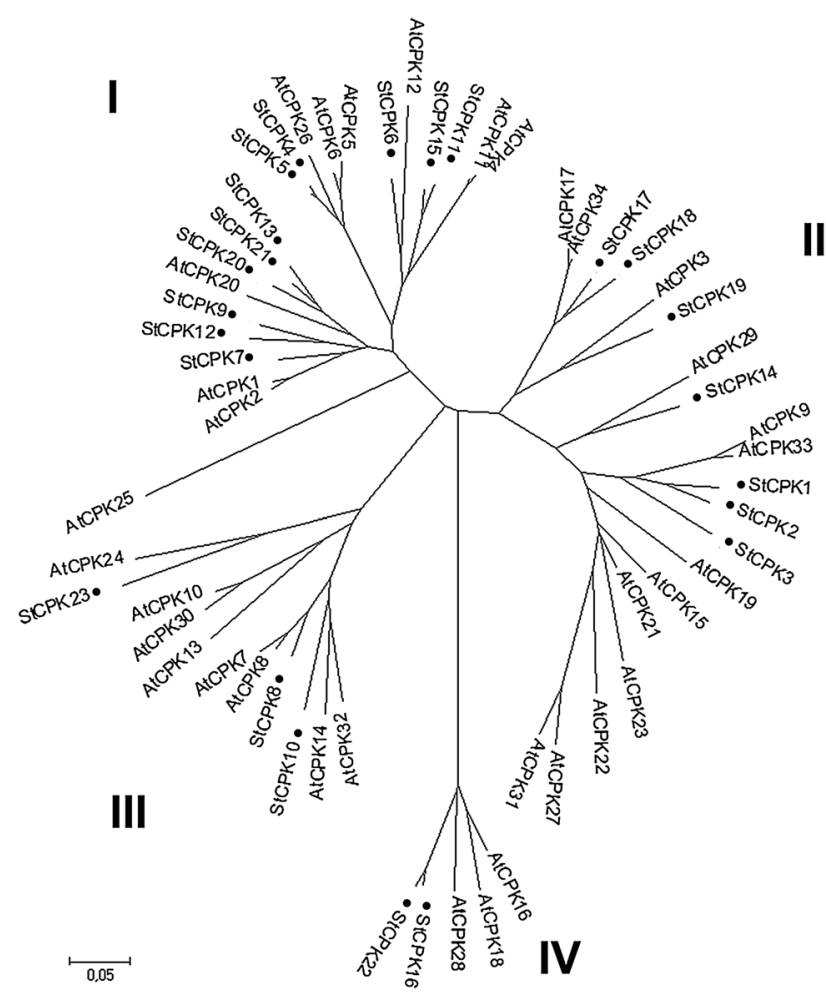

Fig. 1 Phylogenetic tree of potato and Arabidopsis CDPKs. The phylogenetic tree was created according to the neighbor-joining method using MEGA 7.00 program based on amino acid sequences of 23 potato (indicated with black dot) and 34 A. thaliana CDPKs
According to Boudet et al. (2001), the intron-exon organization and the type of the introns reflect the evolutionary history of some gene families. The potato $C D P K$ s were examined in this respect to obtain further insight into their evolution. Each of the previously identified four subfamilies showed similar intron-exon organization of genes within the family and markedly different patterns between them (Supplementary material 6). Most of the 11 StCDPKs from the first subfamily had six or seven introns, all the genes from the second and third subfamilies had seven or eight introns, and those from the fourth subfamily had the highest number of introns, eleven. Since for $S t C P K 5$ from the first subfamily only the cDNA sequence is available, its exon-intron organization could not be determined.

\section{Chromosomal distribution of potato CDPK genes}

To establish the chromosomal locations of the encoding genes, nucleotide sequences of each $S t C D P K$ were used to search the potato genome database using BLASTN. The genes were found on 11 out of the potato 12 chromosomes (except chromosome 9). Five chromosomes had only a single $C D P K$ gene each: chromosome 2-StCPK22; chromosome 3-StCPK16; chromosome 4-StCPK14; chromosome 7-StCPK2; chromosome 8-StCPK19. Four chromosomes carried two CDPK genes each: chromosome 5-StCPK6 and StCPK7; chromosome 6-StCPK11 and StCPK23; chromosome 11-StCPK15 and StCPK17; chromosome 12-StCPK1 and StCPK18. Three CDPK genes were localized on chromosome 1-StCPK8, StCPK9 and StCPK20, and five genes: StCPK4, StCPK10, StCPK12, StCPK13 and StCPK21 on chromosome 10 (Table 1). On some chromosomes the StCDPKs form clusters, which suggests recent gene duplication. Such a differential genomic distribution of the $S t C D P K s$ suggests gradual expansion of this gene family.

\section{Organ-specific expression of potato $C D P K$ genes}

Various potato organs obtained from $S$. tuberosum cv Bzura, such as young and mature leaves, young shoots, stems, roots, stolons, swollen stolons, flowers and tubers were used for expression profiling of $C D P K s$ by RT-qPCR. Transcripts of all $23 C D P K s$ were present in all the samples analysed, although their level varied greatly (Fig. 2 and Supplementary material 7). The organs differed from one another not only in the overall level but also in the spectrum of the expressed $C D P K s$. Highly similar patterns of expression were observed for two pairs of organs: stolons and young shoots, and young and mature leaves, respectively. The highest level of overall StCDPKs expression was found in young shoots and stolons, mainly of $S t C P K 2,4,5,12,15,16,17$, and 22. Roots and flowers showed a medium level of CDPKs expression, 
while in stems, tubers, swollen stolons and leaves (young and mature), the expression was the lowest and generally similar in all these organs (Fig. 2).

StCPK6, 7, 13 and 18 were expressed mostly in flowers, StCPK4, 5, 12, 15, 17 and 22 in young shoots, roots and stolons. Transcripts of StCPK1, 13, 14, and 19 were hardly detectable in some of the organs analysed and were sometimes even below the limits of detection (Supplementary material 7). It seems therefore likely that some CDPKs may be expressed only in response to certain stimuli, at specific developmental stages, and/or in certain cell types.

Summing up, the potato $C D P K s$ exhibit quite complex organ-specific expression patterns, suggesting that some function in defined tissues or developmental stages, while others have broader functions.

\section{Expression of CDPKs in Solanum leaves genotypes treated with elicitor from $P$. infestans}

To learn more about the potential function of the CDPKs in plant disease resistance, kinetics of all the $C D P K$ genes was investigated in potato leaves treated with an elicitor-a culture filtrate $(\mathrm{CF})$ of $P$. infestans. For comparison we used leaves from three Solanum genotypes showing substantially different susceptibility to the pathogen: $S$. tuberosum cv Bzura, S. tuberosum clone H-8105 and Solanum scabrum exhibiting respectively field resistance, susceptibility and non-host resistance to $P$. infestans. Changes in expression of $15 C D P K s$ were observed after the elicitor treatment:

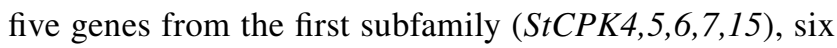
from the second subfamily (StCPK1,2,3,14,17,18), three from the third subfamily $(\operatorname{StCPK8}, 10,23)$ and one from the fourth subfamily (StCPK16) (Fig. 3). Interestingly, in the non-host $S$. scabrum an increase in gene expression occurred between 0.5 and $6 \mathrm{~h}$ after CF treatment, reaching for $S t C P K 23$ ca. $315 \%$ compared to water-treated control (100\%) (Supplementary material 8). In the susceptible $\mathrm{H}-8105$, also StCPK23 was the most strongly induced (430\% of control) but only at prolonged treatment (18-30 h). In the field resistant Bzura leaves, the maximal transcript level was noticed between 6 and $18 \mathrm{~h}$ after the elicitor treatment, and the increase was the highest for StCPK4 (264\% of control).

\section{Activity of CDPKs after treatment with elicitor from $P$. infestans}

To check the influence of the $P$. infestans elicitor on the CDPK kinase activity, we determined the enzymatic activity using the in-gel kinase assay in the presence of calcium ions and, as a negative control, without calcium ions. The activity was studied in leaf extracts prepared from the three different Solanum genotypes treated with the elicitor from $P$. infestans (CF) for between 0 and $24 \mathrm{~h}$. In all the genotypes studied the activity of CDPKs increased in response to the CF treatment, but with different kinetics and maximal intensity (Fig. 4). In the resistant Bzura genotype the CDPKs activity rose gradually between 0.5 and $3 \mathrm{~h}$ of treatment to reach ca. $155 \%$ of the control level and remained elevated (ca. 130-150\%) until the end of the experiment $(24 \mathrm{~h})$. In contrast, in the susceptible clone H-8105, after an early increase to about $130 \%$ of control, the CDPKs activity returned to the control level after $6 \mathrm{~h}$ and remained at that level. In non-host $S$. scabrum the CDPKs activity increased gradually to reach a maximum at $6 \mathrm{~h}$ of CF treatment (193\% of control), remained elevated until the 18th hour and then dropped rapidly to the control level.

Thus, in the resistant genotypes a progressive, marked and long-lasting increase of the kinase activity was observed while the susceptible genotype only showed early, weak and transient activation of the CDPKs. These results suggest a correlation between CDPK activation and resistance of potato against $P$. infestans.

\section{Discussion}

Potato is one of a major crops sustaining the world's population owing to the high nutritional value of its underground tubers. Understanding the signalling pathways that regulate its development and stress responses is key to improving the potato yield, disease resistance, storability and dietary properties.

Calcium-dependent protein kinases (CDPKs), one of the largest groups of plant calcium sensors, bind calcium ions directly which modulates their activity. The calcium-activated kinases regulate diverse developmental processes and defence responses of plants.

The present comprehensive study of $C D P K$ genes in the potato was made possible by the availability of the complete genomic sequence (Potato Genome Sequencing Consortium 2011) and provides a foundation for further functional investigation of this important gene family in Solanaceae. The potato genome encodes at least $23 C D P K s$ similar to the 20-40 CDPK genes present in most other plants. The expansion of gene families in plant genomes is believed to have occurred by various mechanisms such as genome-wide, tandem and dispersed duplications. The potato genome appears to exhibit high plasticity, as gene loss or duplication events and other structural mutations are found with high frequency (Potato Genome Sequencing Consortium 2011).

The domain organization of the 23 potato CDPKs is typical for the CDPKs from other plant species. All potato CDPKs have four EF-hands, and 14 of them contain myristoylation motifs indicating that they undergo the modification promoting protein-membrane and protein-protein interactions (Xu et al. 2015). In potato, like in rice, maize 

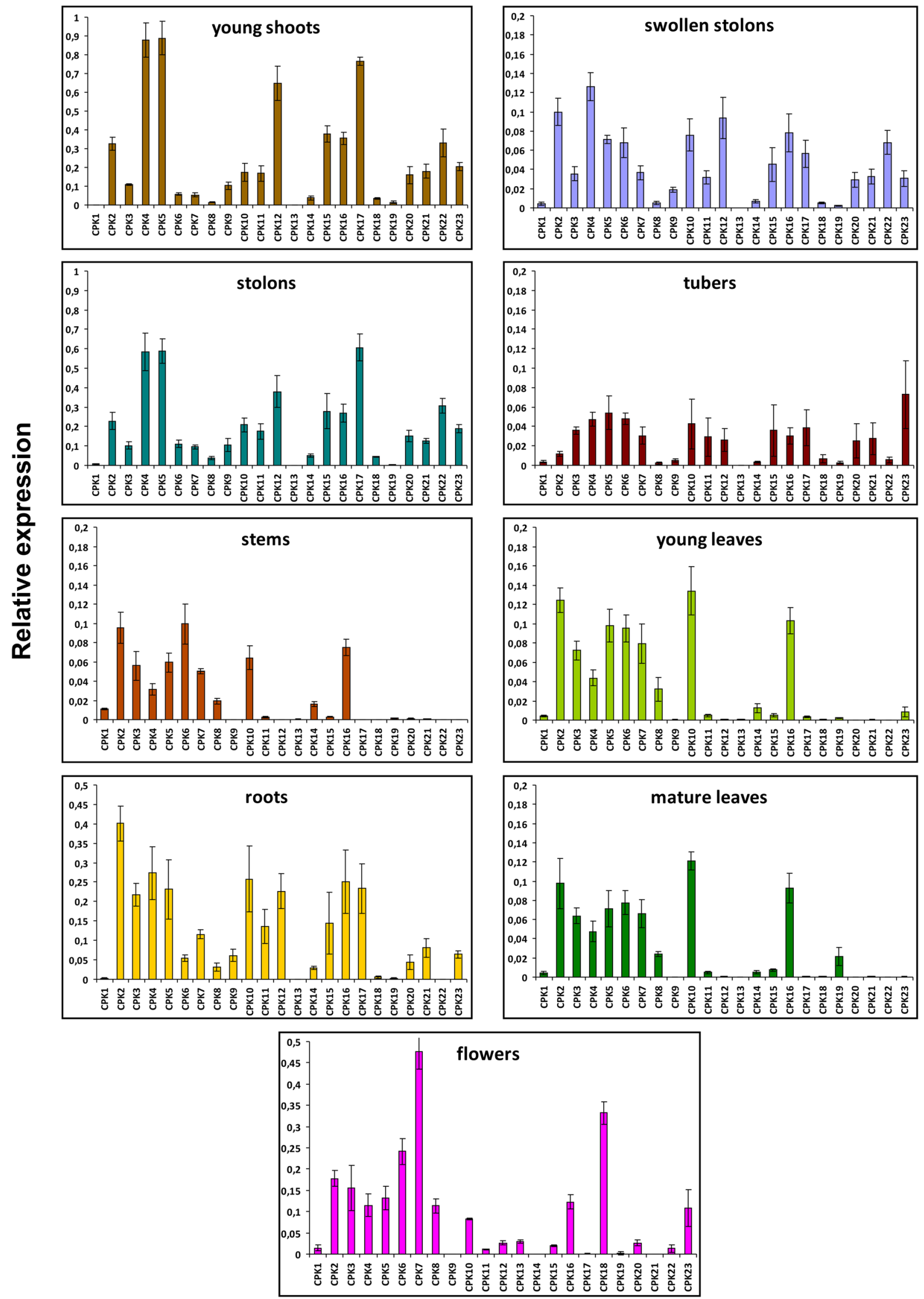
4Fig. 2 Expression of individual potato $C P K$ genes in the indicated organs. Please note different ordinate scales for different organs. Expression profiles are represented by at least three independent experiments each in two replicates. The data are the mean values $\pm \mathrm{SD}(n \geq 6)$. Relative expression is presented in relation to reference genes

and Arabidopsis thaliana, some of the CDPK-like protein kinases ( 8 in potato) contain less than four, or even none, EF-hands. In the potato genome the $23 C D P K s$ genes are distributed apparently randomly among chromosomes. In the tomato 29 SlCDPKs genes are distributed in all chromosomes also highly unevenly, which the authors interpreted as indicating evolution events and recent expansion of the family (Wang et al. 2015).

CDPKs are involved in various physiological processes at different stages of plant development (Liu et al. 2016). To investigate the expression profiles of the $C D P K$ genes in potato development, we determined their transcript levels in different organs such as young and mature leaves, young shoots, stems, roots, stolons, swollen stolons, flowers and tubers. Although transcripts of at least some $C D P K$ s were detected in all the organs, their expression levels varied greatly between individual genes and also between organs. Only in two pairs of organs, young and mature leaves, and stolons and young shoots, the expression patterns were highly similar. Notably, young shoots, roots and stolons showed particularly high expression of $C D P K s$ mostly from the first subfamily $(S t C P K 4,5,12,15)$ and $S t C P K 17$ from the second subfamily.

Interestingly, $S t C P K 3$ is highly similar in its amino acid sequence to tobacco NtCDPKl and tomato LeCPKl (Yoon et al. 1999; Rutschmann et al. 2002). These three genes are expressed at a very high level in roots. A down-regulation of $N t C D P K 1$ in transgenic tobacco resulted in smaller plants showing abnormal root development, with reduced lateral root formation and impaired elongation (Lee et al. 2006). By analogy, StCPK3 likely participates in the development of main and lateral roots (Grandellis et al. 2012).

Four StCPKs: StCPK6, 7, 13 and 18, were expressed exclusively in flowers, indicating their possible role in flower development. This is in concert with earlier results. According to Schulz et al. (2013), CDPKs have a major role in pollen tube growth. Twelve members of the Arabidopsis $C D P K$ gene family are predominantly expressed in pollen (Myers et al. 2009). For AtCPK2/AtCPK20 and AtCPK17/AtCPK34, a role in pollen tube growth has been demonstrated experimentally in double mutant lines (Gutermuth et al. 2013). StCPK13, expressed exclusively in potato flowers, is very similar to AtCPK2/AtCPK20, while $S t C P K 18$, highly expressed in potato flowers, is closely related to AtCPK17/AtCPK34. AtCPK2/CPK20 and $A t C P K 17 / A t C P K 34$ are involved in the regulation of pollen tube growth, and AtCPK2/CPK20 influence the anion channel SLAH3 (Gutermuth et al. 2013). Moreover, PiCDPK1 from petunia (Petunia inflata), similar to AtCPK17/AtCPK34, has also been implicated in pollen tube growth polarity (Yoon et al. 2006). One of the maize $C D P K$ genes (designated by us as $Z m C P K 7$ according to the nomenclature by $\mathrm{Ma}$ et al. 2013), also similar to AtCPK17/AtCPK34, is expressed specifically during late stages of pollen development. Specific inhibition of the $Z m C P K 7$ expression by antisense oligonucleotide resulted in impaired germination and growth of pollen tube (Estruch et al. 1994). According to Ray et al. (2007), OsCPK2 and 14 from rice that show homology to PiCDPKI and AtCPK17 and 34, and $O s C P K 25$ and 26, highly similar to ZmCPK7, are expressed during late panicle development and thus could be involved in a similar function during pollen maturation and/or pollen tube growth.

A process typical for potato is tuberization that results in differentiation of a specialized shoot (stolon) into a storage organ (the tuber). Tuber development is a tightly controlled process triggered by both external and internal factors; among them calcium ions and protein kinases play an important role (Balamani et al. 1986; Raíces et al. 2003). It has been suggested that sequential activation of specific CDPKs with distinct biochemical properties and subcellular localization could be essential for the co-ordination of multiple $\mathrm{Ca}^{2+}$ signals triggered upon tuberization (Raíces et al. 2003). StCDPK1 and StCDPK3, with different substrate specificities and cellular distribution, were found associated with early and induced stolons, respectively. StCDPK1 was expressed in tuberizing stolons and sprouting tubers (Raíces et al. 2001; Gargantini et al. 2009), whereas expression of $S t C D P K 3$ was abundant in stolons, roots and leaves (Grandellis et al. 2012). Transcript of another CDPK, StCDPK2, was present in all plant tissues studied and during different developmental processes - sprouting and tuberization (Giammaria et al. 2011); its level was the highest in actively growing young leaves. In our experimental system, three $C D P K s$ described before were expressed in all organs analysed, although expression of $S t C P K 1$ was very low. $S t C P K 2$ and $S t C P K 3$ were mainly expressed in roots, stolons, young shoots, and flowers. StCPK4, 5, 12, 15, 16, and 17 were highly expressed in stolons and were the major ones in a rapidly growing organ-the young shoots. The differences in expression of individual CDPKs likely correlate with their participation in specific signal transduction pathways in different organs.

Accumulating evidence indicates that CDPKs play an important role in plant immunity. For example, Fu et al. (2013) demonstrated that overexpression of constitutively active OsCPK10 enhanced Arabidopsis resistance against Pseudomonas syringae pv. tomato. Our present study indicated a likely involvement of CDPKs in Solanum species 


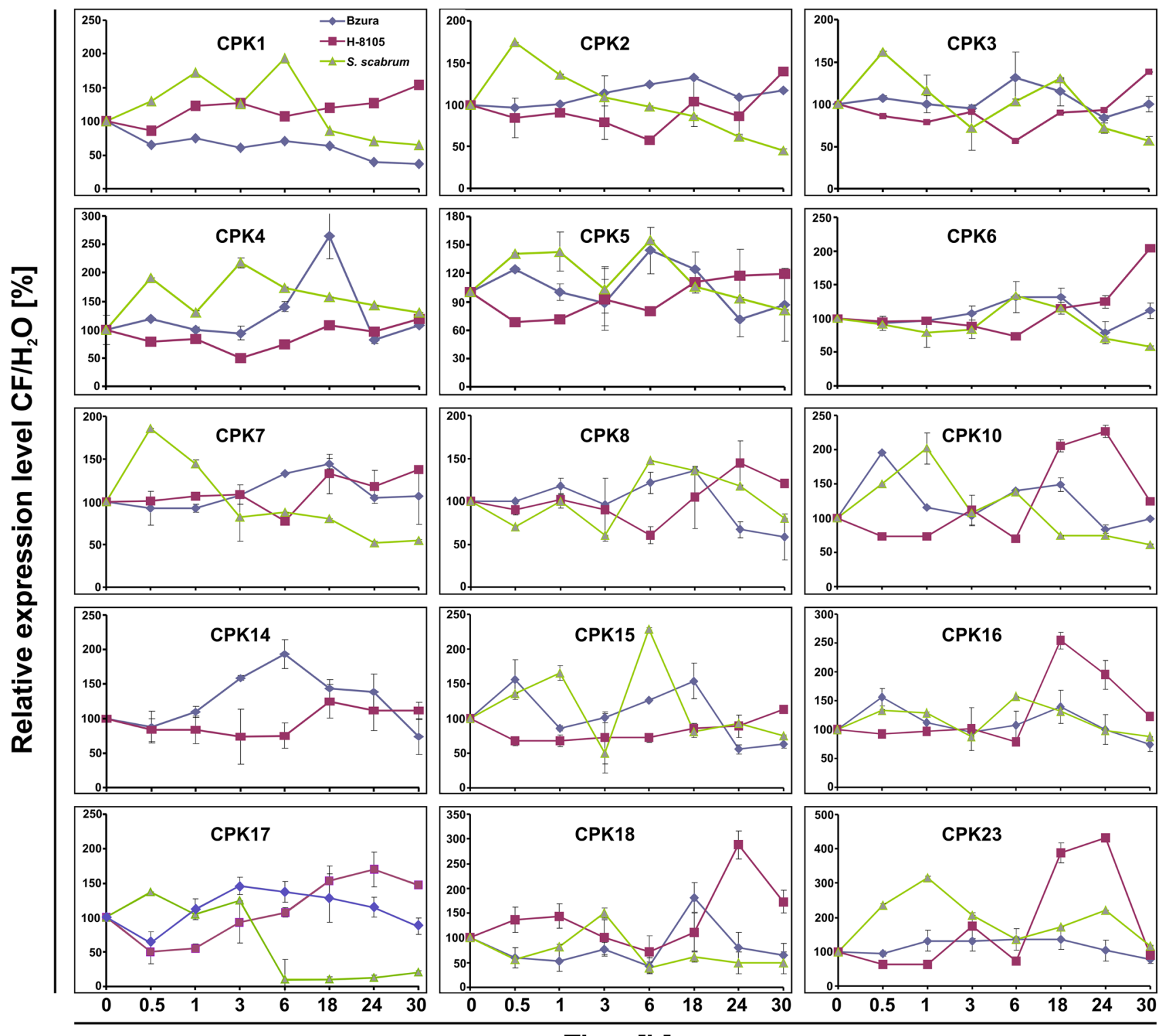

Time [h]

Fig. 3 Expression of various $C D P K$ genes in elicitor-treated leaves of three Solanum genotypes expressed as \% of control levels. Transcript levels at time-points indicated are expressed relative to control

in response to an elicitor, a culture filtrate $(\mathrm{CF})$ from the pathogenic oomycete Phytophthora infestans causing late blight, the most destructive potato disease. We determined expression profiles of all the potato CDPKs and CDPK activities in three Solanum genotypes expressing different types and level of resistance against $P$. infestans. Expression of all $15 C D P K s$ and the kinase activity increased after $\mathrm{CF}$ treatment in all these genotypes, but with strikingly different patterns in the sensitive and the resistant ones. These results are in agreement with the earlier findings of Vleeshouwers et al. (2000). Their cytological study indicated that the severity and timing of defence response varied depending value determined as the average of all time points in control (watertreated) leaves. At least two independent biological series of each experiment were performed. Data are mean values $\pm \operatorname{SD}(n \geq 4)$

on the form and level of resistance exhibited by a Solanum genotype. Those authors suggested that in the Solanum/P. infestans interaction resistance is a quantitative rather than a qualitative trait. In our experimental system the magnitude and duration of gene induction and activity upregulation of the CDPKs correlated positively with the level of resistance of the Solanum genotypes to P. infestans.

Some authors have documented a relation between CDPKs and production of reactive oxygen species (ROS). Thus, Kobayashi et al. (2007) observed phosphorylation of NADPH oxidase by StCDPK4 and StCDPK5 that resulted in oxidative burst. We observed a positive correlation 

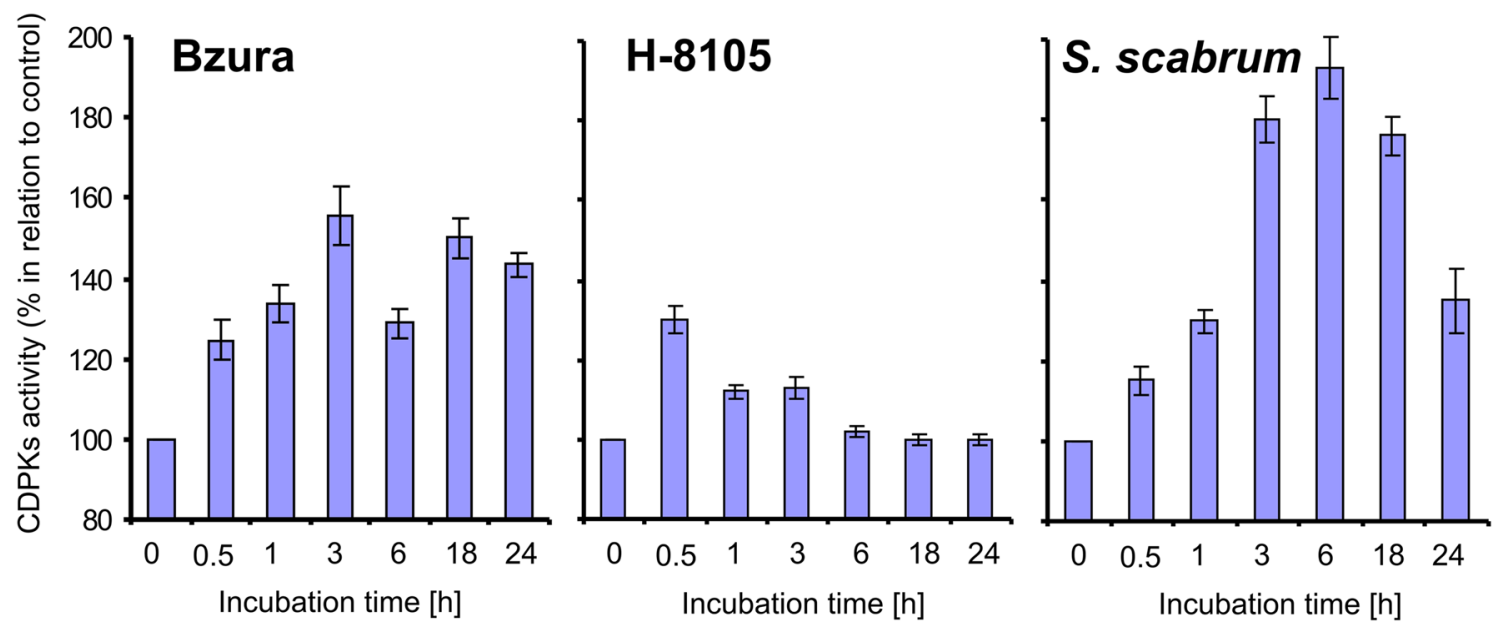

Fig. 4 Activity of CDPK in elicitor-treated leaves of three Solanum genotypes shown as \% of control levels at various time points. "Zero" denote average values represented by control leaves treated with

between increased activity and gene expression of CDPKs (present results) and ROS generation (Polkowska-Kowalczyk et al. 2004) in resistant genotypes in response to $P$. infestans, but not such correlation was found for the susceptible H-8105. Taken together, the earlier and present results concerning different Solanum genotypes (Polkowska-Kowalczyk et al. 2004, 2011) indicate that an effective defence against $P$. infestans involves cooperation among the diverse elicitor-induced processes.

In conclusion, the potato genome contains at least 23 members of the $C D P K$ gene family. Most of these genes exhibit markedly different expression levels in various organs, suggesting that they play specific different roles in potato development. Increased CDPK expression and activity in response to the elicitor from $P$. infestans indicates involvement of CDPKs in the defence against this pathogen. Due to the high economic significance of the potato, it is imperative to study defence mechanisms occurring in response to pathogen attack.

Acknowledgements We wish to thank Prof. Grażyna Dobrowolska for helpful discussion and Prof. Jan Fronk for critical reading of the manuscript. The authors are also grateful to Irena Dzikowska for technical support in plant cultures. We are grateful to IHAR-PIB, Młochów Research Center, Poland for providing the isolate of $P$. infestans (isolate MP618) and Solanum genotypes.

Funding This work was supported by the National Science Centre, Poland, project 2012/05/B/NZ3/00911 and partially by the Ministry of Science and Higher Education, Poland, Project 0329/B/P01/2008/34. water from 0 to $24 \mathrm{~h}$. At least two independent biological series of experiments were performed. Data are mean values $\pm \mathrm{SD}(n \geq 4)$

\section{Compliance with ethical standards}

Conflict of interest The authors declare that they have no conflict of interest.

Ethical approval This article does not contain any studies with human participants or animals performed by any of the authors.

Open Access This article is distributed under the terms of the Creative Commons Attribution 4.0 International License (http://creativecommons.org/licenses/by/4.0/), which permits unrestricted use, distribution, and reproduction in any medium, provided you give appropriate credit to the original author(s) and the source, provide a link to the Creative Commons license, and indicate if changes were made.

\section{References}

Asano T, Tanaka N, Yang G, Hayashi N, Komatsu S (2005) Genomewide identification of the rice calcium-dependent protein kinase and its closely related kinase gene families: comprehensive analysis of the CDPKs gene family in rice. Plant Cell Physiol 46(2):356-366

Baillie BK, Belda-Baillie CA, Maruyama T (2000) A calciumdependent protein kinase functions in wound healing in Ventricaria ventricosa (chlorophyta). J Phycol 36:1145-1152

Balamani V, Veluthambi K, Poovaiah BW (1986) Effect of calcium on tuberization in potato (Solanum tuberosum L.). Plant Physiol 80:856-858

Billker O, Lourido S, Sibley LD (2009) Calcium-dependent signalling and kinases in apicomplexan parasites. Cell Host Microbe 5:612-622

Boudet N, Aubourg S, Toffano-Nioche C, Kreis M, Lecharny A (2001) Evolution of intron/exon structure of DEAD helicase family genes in Arabidopsis, Caenorhabditis, and Drosophila. Genome Res 11:2101-2114 
Boudsocq M, Sheen J (2013) CDPKs in immune and stress signalling. Trends Plant Sci 18:30-40

Boudsocq M, Willmann MR, McCarmack M, Lee H, Shan L, He P, Bush J, Cheng SH, Sheen J (2010) Differential innate immune signalling via $\mathrm{Ca}^{2+}$ sensor protein kinases. Nature 464:418-422

Bradford MM (1976) A rapid and sensitive method for quantitation of microgram quantities of protein utilizing the principle of protein-dye binding. Anal Biochem 72:248-254

Broad Institute of Harvard and MIT (2010) Phytophthora infestans Sequencing Project. https://www.broadinstitute.org

Campo S, Baldrich P, Messeguer J, Lalanne E, Coca M, San Segundo B (2014) Overexpression of a calcium-dependent protein kinase confers salt and drought tolerance in rice by preventing membrane lipid peroxidation. Plant Physiol 165:688-704

Cheng S-H, Willmann MR, Chen H-C, Sheen J (2002) Calcium signaling through protein kinases. The Arabidopsis calcium-dependent protein kinase gene family. Plant Physiol 129:469-485

Coca M, San Segundo B (2010) AtCPK1 calcium-dependent protein kinase mediates pathogen resistance in Arabidopsis. Plant J 63:526-540

Dubrovina AS, Kiselev KV, Khristenko VS, Aleynova OA (2017) The calcium-dependent protein kinase gene VaCPK29 is involved in grapevine responses to heat and osmotic stresses. Plant Growth Regul 82:79-89

Estruch JJ, Kadwell S, Merlin E, Crossland L (1994) Cloning and characterization of a maize pollen-specific calcium-dependent calmodulin-independent protein kinase. Proc Natl Acad Sci USA 91:8837-8841

Fu L, Yu X, An Ch (2013) Overexpression of constitutively active OsCPK10 increases Arabidopsis resistance against Pseudomonas syringae pv. tomato and rice resistance against Magnaporthe grisea. Plant Physiol Biochem 73:202-210

Gao X, Chen X, Lin W, Chen S, Lu D, Niu Y, Li L, Cheng C, McCormack M, Sheen J (2013) Bifurcation of Arabidopsis NLR immune signalling via $\mathrm{Ca}^{2+}$-dependent protein kinases. PloS Pathol 9:e1003127

Gargantini PR, Giammaria V, Grandellis C, Feingold SE, Maldonado S, Ulloa RM (2009) Genomic and functional characterization of StCDPK1. Plant Mol Biol 70:153-172

Giammaria V, Grandellis C, Bachmann S, Gargantini PR, Feingold SE, Bryan G, Ulloa RM (2011) StCDPK2 expression and activity reveal a highly responsive potato calcium-dependent protein kinase involved in light signalling. Planta 233:593-609

Grandellis C, Giammaria V, Bialer M, Santin F, Lin T, Hannapel DJ, Ulloa RM (2012) The novel Solanum tuberosum calcium dependent protein kinase, StCDPK3, is expressed in actively organs. Planta 236:1831-1848

Gutermuth T, Lassig R, Portes M-T, Maierhofer T, Romeis T, Borst JW, Hedrich R, Feijó JA, Konrad KR (2013) Pollen tube growth regulation by free anions depends on the interaction between the anion channel SLAH3 and calcium-dependent protein kinases CPK2 and CPK20. Plant Cell 25:4525-4543

Harmon AC, Gribskov M, Gubrium E, Harper JF (2001) The CDPK superfamily of protein kinases. New Phytol 151:175-183

Hrabak EM, Dickmann LJ, Satterlee JS, Sussman MR (1996) Characterization of eight new members of the calmodulin-like domain protein kinase gene family of Arabidopsis thaliana. Plant Mol Biol 31:405-412

Hrabak EM, Chan CWM, Gribskov M, Harper JF, Choi JH, Halford N, Kudla J, Luan S, Nimmo HG, Sussman MR, Thomas M, Walker-Simmons K, Zhu JK, Harmon AC (2003) The Arabidopsis CDPK-SnRK superfamily of protein kinases. Plant Physiol 132:666-680

Hu B, Jin J, Guo A-Y, Zhang H, Luo J, Gao G (2015) GSDS 2.0: an upgraded gene feature visualization server. Bioinformatics $31: 1296-1297$
Hu Z, Lv X, Xia X, Zhou J, Shi K, Yu J, Zhou Y (2016) Genomewide identification and expression analysis of calcium-dependent protein kinase in tomato. Front Plant Sci 7:469. https://doi. org/10.3389/fpls.2016.00469

Ivashuta S, Liu J, Liu J, Lohar DP, Haridas S, Bucciarelli B, VandenBosch KA, Vance CP, Harrison MJ, Gantt JS (2005) RNA interference identiWes a calcium-dependent protein kinase involved in Medicago truncatula root development. Plant Cell 17:2911-2921

Kamiyoshihara Y, Iwata M, Fukaya T, Tatsuki M, Mori H (2010) Turnover of LeACS2, a wound-inducible 1-aminocyclopropane1 -carboxylic acid synthase in tomato, is regulated by phosphorylation/dephosphorylation. Plant J 64:140-150

Klimecka M, Muszyńska G (2007) Structure and functions of plants calcium-dependent protein kinases. Acta Biochim Polon 54(2):219-233

Kobayashi M, Ohura I, Kawakita K, Yokota N, Fujiwara M, Shimamoto K, Doke N, Yoshioka H (2007) Calcium-dependent protein kinases regulate the production of reactive oxygen species by potato NADPH oxidase. Plant Cell 19:1065-1080

Kong X, Lv W, Jiang S, Zhang D, Cai G, Pan J, Li D (2013) Genomewide identification and expression analysis of calcium-dependent protein kinase in maize. BMC Genom 14:433. https://doi. org/10.1186/1471-2164-14-433

Kumar GNM, Iyer S, Knowles NR (2007) Extraction of RNA from fresh, frozen, and lyophilized tuber and root tissues. J Agric Food Chem 55:1674-1678

Kumar S, Stecher G, Tamura K (2016) MEGA7: molecular evolutionary genetics analysis version 7.0 for bigger datasets. Mol Biol Evol 33:1870-1874

Larkin MA, Blackshields G, Brown NP, Chenna R, McGettigan PA, McWiliam H, Valentiv F, Wallace IM, Wilm A, Lopez R, Thompson JD, Gibson TJ, Higgins DG (2007) Clustal W and Clustal X version 2.0. Bioinformatics 23: 2947-2948

Lee SS, Yoon GM, Rho EJ, Moon E, Pai HS (2006) Functional characterization of NtCDPK1 in tobacco. Mol Cells 28:141-146

Li AL, Zhu YF, Tan XM, Wang X, Wei B, Guo HZ, Zhang ZL, Chen XB, Zhao GY, Kong XY (2008) Evolutionary and functional study of the CDPK gene family in wheat (Triticum aestivum L.). Plant Mol Biol 66:429-443

Liu W, Li W, He Q, Khan Daud M, Chen J, Zhu S (2014) Genomewide survey and expression analysis of calcium-dependent protein kinase in Gossypium raimondii. PLoS ONE 9:e98189. https://doi. org/10.1371/journal.pone.0098189

Liu H, Che Z, Zeng X, Zhou X, Sitoe HM, Wang H, Yu D (2016) Genome-wide analysis of calcium-dependent protein kinases and their expression patterns in response to herbivore and wounding stresses in soybean. Funct Integr Genom 16:481-493

Lu SX, Hrabak EM (2002) An Arabidopsis calcium-dependent protein kinase is associated with the endoplasmic reticulum. Plant Physiol 128:1008-1021

Ma P, Liu J, Yang X, Ma R (2013) Genome-wide identification of the maize calcium-dependent protein kinase gene family. Appl Biochem Biotechnol 169:2111-2125

McCurdy DW, Harmon AC (1992) Calcium-dependent protein kinase in the green alga Chara. Planta 188:54-61

Myers C, Romanowsky SM, Barron YD, Garg S, Azuse CL, Curran A, Davis RM, Hatton J, Harmon AC, Harper JF (2009) Calciumdependent protein kinases regulate polarized tip growth in pollen tubes. Plant J 59:528-539

Plich J, Tatarowska B, Lebecka R, Śliwka J, Zimnoch-Guzowska E, Flis B (2015) R2-like gene contributes to resistance to Phytophthora infestans in polish potato cultivar Bzura. Am J Potato Res 92:350-358

Polkowska-Kowalczyk L, Wielgat B, Maciejewska U (2004) The elicitor-induced oxidative processes in leaves of Solanum species with 
differential polygenic resistance to Phytophthora infestans. J Plant Physiol 161:913-920

Polkowska-Kowalczyk L, Wielgat B, Maciejewska U (2011) Involvement of phospholipase $A_{2}$ in the response of Solanum species to an elicitor from Phytophthora infestans. Acta Physiol Plant 33:2521-2531

Potato Genome Sequencing Consortium (2011) Genome sequence and analysis of the tuber crop potato. Nature 475:189-197

Raíces M, Chico JM, Téllez-Iňón MT, Ulloa RM (2001) Molecular characterization of StCDPK1, a calcium-dependent protein kinase from Solanum tuberosum that is induced at the onset of tuber development. Plant Mol Biol 46:591-601

Raíces M, Gargantini PR, Chinchilla D, Crespi M, Téllez-Iňón MT, Ulloa RM (2003) Regulation of CDPK isoforms during tuber development. Plant Mol Biol 52:1011-1024

Ray S, Agarwal P, Arora R, Kapoor S, Tyagi AK (2007) Expression analysis of calcium-dependent protein kinase gene family during reproductive development and abiotic stress conditions in rice (Oryza sativa L. ssp. indica). Mol Genet Genom 278:493-505

Romeis T, Herde M (2014) From local to global: CDPKs in systemic defence signalling upon microbial and herbivore attack. Curr Opin Plant Biol 20:1-10

Romeis T, Ludwig AA, Martin R, Jones JD (2001) Calcium-dependent protein kinases play an essential role in a plant defence response. EMBO J 20:5556-5567

Rutschmann F, Stalder U, Piotrowski M, Oecking C, Schaller A (2002) LeCPK1, a calcium-dependent protein kinase from tomato: plasma membrane targeting and biochemical characterization. Plant Physiol 129:156-168

Schulz P, Herde M, Romeis T (2013) Calcium-dependent protein kinases: hubs in plant stress signaling and development. Plant Physiol 163:523-530

Sigrist CJA, de Castro E, Cerutti L, Cuche BA, Hulo N, Bridge A, Bougueleret L, Xenarios I (2013) New and continuing developments at PROSITE. Nucleic Acids Res 41:D344-D347. https:// doi.org/10.1093/nar/gks1067

Szczegielniak J, Klimecka M, Liwosz A, Ciesielski A, Kaczanowski S, Dobrowolska G, Harmon AC, Muszyńska G (2005) A woundresponsive and phospholipid-regulated maize calcium-dependent protein kinase. Plant Physiol 139:1970-1983

Szczegielniak J, Borkiewicz L, Szurmak B, Lewandowska-Gnatowska E, Statkiewicz M, Klimecka M, Ciesla J, Muszynska G (2012) Maize calcium-dependent protein kinase (ZmCPK11): local and systemic response to wounding, regulation by touch and components of jasmonate signaling. Physiol Plant 146:1-14
Tamura K, Nei M, Kumar S (2004) Prospects for inferring very large phylogenies by using the neighbor-joining method. Proc Natl Acad Sci USA 101:11030-11035

Ulloa RM, Raíces M, MacIntosh GC, Maldonado S, Téllez-Iňón MT (2002) Jasmonic acid affects plant morphology and calciumdependent protein kinase expression and activity in Solanum tuberosum. Physiol Plant 115:417-427

Vandesompele J, De Preter K, Pattyn F, Poppe B, Van Roy N, De Paepe A, Speleman F (2002). Accurate normalization of realtime quantitative RT-PCR data by geometric averaging of multiple internal control genes. Genome Biol. https://doi.org/10.1186/ gb-2002-3-7-research0034

Vleeshouwers VGAA, van Dooijweert W, Govers F, Kamoun S, Colon LT (2000) The hypersensitive response is acciociated with host and nonhost resistance to Phytophthora infestans. Planta 210:853-864

Wang J-P, Xu Y-P, Munyampundu J-P, Liu T-Y, Cai X-Z (2015) Calcium-dependent protein kinase (CDPK) and CDPK-related kinase (CRK) gene families in tomato: genome-wide identification and functional analyses in disease resistance. Mol Genet Genom. https://doi.org/10.1007/s00438-015-1137-0

Xu X, Liu M, Lu L, He M, Qu W, Xu Q, Qi X, Chen X (2015) Genome-wide analysis and expression of the calcium-dependent protein kinase gene family in cucumber. Mol Genet Genom 290:1403-1414

Yoon GM, Cho HS, Ha HJ, Liu JR, Lee HS (1999) Characterization of NtCDPK1, a calcium-dependent protein kinase gene in Nicotiana tabacum, and the activity of its encoded protein. Plant Mol Biol 39:991-1001

Yoon GM, Dowd PE, Gilroy S, McCubbin AG (2006) Calciumdependent protein kinase isoforms in Petunia have distinct functions in pollen tube growth, including regulating polarity. Plant Cell 18:867-878

Zhang XS, Choi JH (2001) Molecular evolution of calmodulin-like domain protein kinases (CDPKs) in plants and protists. J Mol Evol 53:214-224

Zhang K, Han Y-T, Zhao F-L, Hu Y, Gao Y-R, Ma Y-F, Zheng Y, Wang Y-J, Wen Y-Q (2015) Genome-wide identification and expression analysis of the CDPK gene family in grape, Vitis spp. BMC Plant Biol 15:164. https://doi.org/10.1186/s12870-015-0552-Z

Zuo R, Hu R, Chai G, Xu M, Qi G, Kong Y, Zhou G (2013) Genomewide identification, classification, and expression analysis of CDPK and its closely related gene families in poplar (Populus trichocarpa). Mol Biol Rep 40:2645-2662 